KINSEY and Grant (1942).-Jl. Gen. Physiol., Vol. XXVI, p. 131.

- (1944).-Brit. Jl. Ophthal., Vol. XXVIII, p. 355.

KINSEY and RoBINSON (1946).-Ji. Biol. Chem., Vol. CLXII, p. 325.

LANDIS (1946).-Ann. N.Y. Acad. Sc., Vol. XLVI, p. 713.

MÜLle R (1935).-Arch. f. Augenheilk., Vol. CIX, p. 434.

MÜLLER and B.USCHKE (1934).-Arch.f. Augenheilk., Vol. CVIII, p. 368.

PALM (1946).-Acta Ophthal., Vol. XXIV, p. 189.

- (1947).-Acta Ophthal., Vol. XXV „ pp. 29, 139.

PARsons (1904-8). - The Pathology of the Eye, London.

RoBerTSON (1939).-Brit. Jl. Ophthal., Vol. XXIII, pp. 106, 170, 243.

RoePKe and Hetherington (1940).-Amer. Jl. Physiol., Vol. CXXX, p. 340.

SCHEIE, MOORE and AdLer (1943).-Arch. of Ophthal.; Vol. XXX, p. 70.

- (1947).-Arch. of Ophthal., Vol. XXXVII, p. 217.

Troncoso (1921).-Amer. Jl. Ophthal., Vol. IV, p. 321.

(1933).-Amer. Jl. Ophthal., Vol. XVI, p. 669.

\title{
PARTICIPATION OF THE OCULAR APPENDAGES IN SYMPATHETIC OPHTHALMIA AND ITS BEARING ON ENUCLEATION
}

BY

BERNARd SAMUELS

NEW YORK

THE special incentive for this paper is my conviction that not infrequently following the enucleation' of the exciting eye in sympathetic ophthalmia a considerable amount of inflamed tissue is left in the orbit. Sufficient emphasis does not seem to be placed on the fact that although sympathetic ophthalmia is primarily a disease of the inner eye yet the appendages may also be involved simultaneously.

\section{Nature of Sympathetic Ophthalmia}

Histologically sympathetic ophthalmia declares itself in the guise of an infiltration of lymphocytes, epithelioid cells and giant cells in the uveal tract of each eye. The peculiarity lies not so much in the elements of the infiltration, which are similar to those of tuberculosis, but rather in the selective affinity that the disease exhibits for uveal tissue. A characteristic feature of the disease is the tendency of the infiltration to expand outward beyond the globe. Inwardly, any involvement of the pigment epithelium and retina is invariably so slight as to be of no real consequence. Nor is the choriocapillaris attacked, apparently because the interspace between the capillaries is composed of tissue that is not typically uveal and therefore is not suitable soil. 


\section{Cause of Sympathetic Ophthalmia}

As far back as 1905 Parsons, in his Pathology of the Eye, expressed his opinion that sympathetic ophthalmia " is an endogenous infection by ultravisible organisms." The accumulated evidence of countless histological examinations of the exciting eye has served to strengthen this theory. Certainly the inflammatory reaction of the tissues attacked presents all the earmarks of a nonpyogenic infection. The most mysterious aspect of the disease is the fact that the virus supposed to be responsible has never been isolated or seen. In any event, the very essence of sympathetic ophthalmia is a perforating wound in one globe through which the virus may enter.

\section{Pathways of the Virus as Revealed by Inflammatory Reaction (OMmitTing Many Minutiae)}

A. Pathway along the uveal tract. Perforations in the region of the ciliary body, which, to borrow a term from Nettleship, is called " the dangerous zone," are the most feared because they are apt to be accompanied by prolapse of the iris and ciliary body, either one of which forms a favourable point from which the virus may travel into the interior of the eye. When the opening is large, the blood supply to the prolapse being little impaired and the part being released from intra-ocular pressure, the reaction may be so great as to attain tumour-like proportions and resemble a staphyloma (Fig. 1). On the other hand, there may be little or no reaction at or near the opening, for with the globe as with any other part of the body, it is possible for bacteria to enter without causing a primary lesion. The advance of the virus posteriorly may be blocked completely by a zone chorioretinitis produced by traction on the part of a.detached retina. Such confinement of the infiltration to the area near the perforation is a most striking anatomical proof of the extra-ocular origin of the virus (Fig. 2).

The development of the infection in the choroid may be divided into two stages. (1) The appearance of small lymphocytic foci in and around the walls of the larger veins. (2) The complete replacement of the vascular layer by the specific infiltration. All of these changes, as a rule, are more advanced in the iris and ciliary bodyanother point in favour of the theory that the virus enters through the wound.

The infiltration is to be found in its purest and heaviest form in the circumpapillary and macular regions of the choroid. Here the least damage is done at the time of the perforation and here the layer is the thickest and the blood supply the richest, 


\section{Participation of the Ocular Appendages in Sympathetic}

OPHTHALMIa AND ITS BEARING, ON ENUClEation

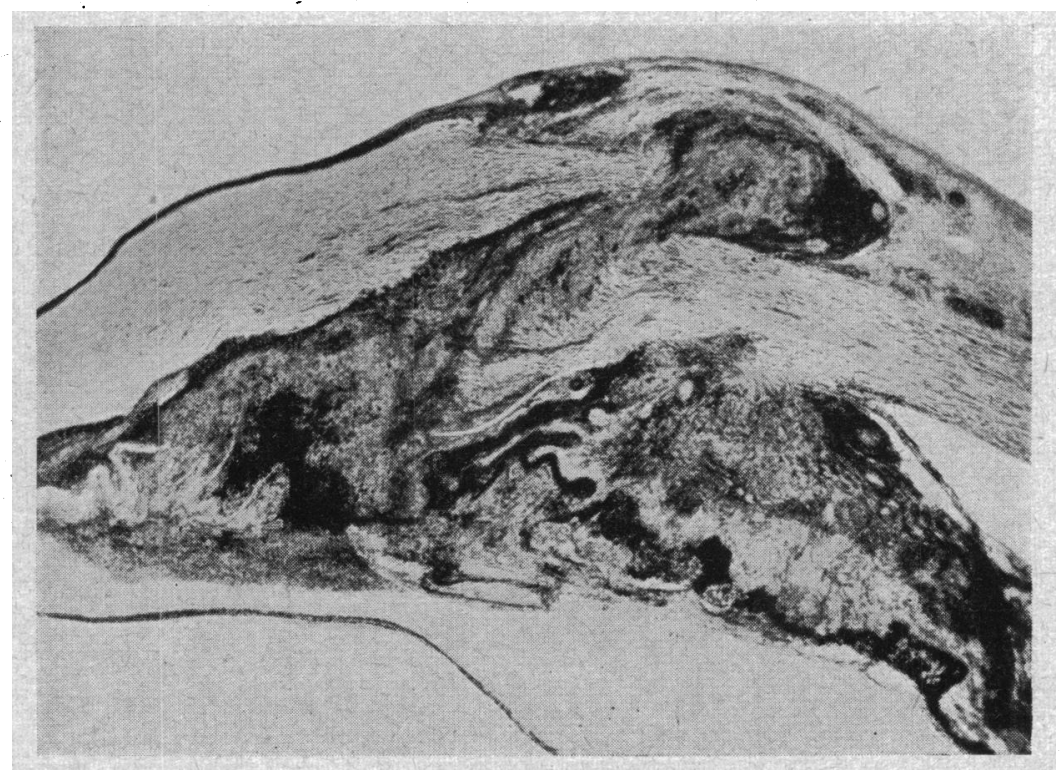

FIg. 1.

Tumour-like extra-ocular nodule of specific infiltration replacing prolapsed iris and simulating staphyloma.

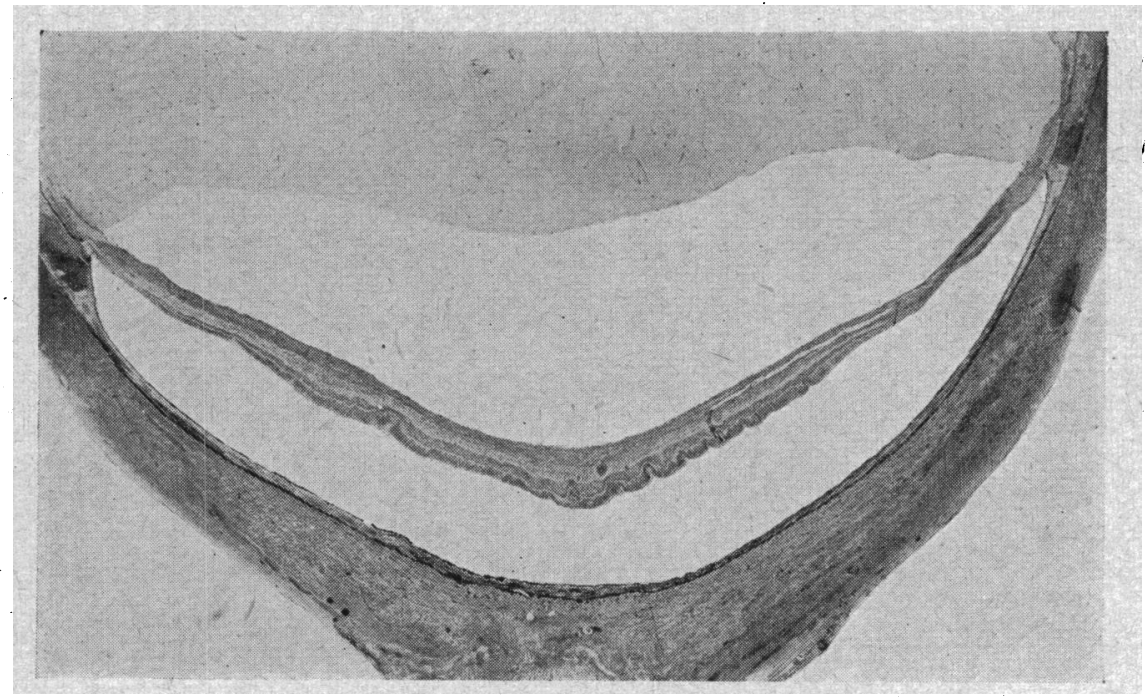

FIG. 2.

On either side a large dense nodule marks the point at which the retina becomes detached and the specific infiltration ends. 
B. Pathway of the virus through the globe into the tissues of the orbit. The virus, judging always by the presence of the infiltration, leaves the inner eye by the same routes as those chosen by the cells of a malignant melanoma of the choroid. It may infiltrate layer after layer of the sclera and at the same time pass through the preformed emissaria. Anteriorly, the root of the iris is a favourite site for the accumulation of the specific cells, thereby clogging the angle and accounting for secondary glaucoma. The pectinate ligament may be destroyed and files of lymphocytes may replace the tissue between the internal and external sulci, leading to the sympathetic staphyloma seen in the worst cases. Rarely nodules occupy Schlemm's canal. Posteriorly, the segment of the sclera facing the muscle funnel is pierced by numerous large emissaria for the passage of the short ciliary arteries and nerves. This part of the sclera may be considered as the dangerous zone for the egress of the virus just as the ciliary region is the dangerous zone for its ingress. The heavy choroidal infiltration passes by continuity into the lamina fusca of the sclera and replaces it. In sympathetic ophthalmia, as in malignant melanoma, every emissarium is a locus minoris resistentiae. The infiltration passes without hindrance through these openings to the episclera and the space of Tenon. The destruction of the outer layers of the sclera proceeds with that of the inner layers. At the same time the middle layers may be permeated with nodules. At the height of the infection the implication of the sclera, through and through, is an outstanding feature of sympathetic ophthalmia. 'The infected sclera may be thought of as fairly reeking with the virus (Fig. 3).

By the union of the parts the virus passes into the insertion of the inferior oblique muscle. Sympathetic nodules have been reported replacing muscle bundles as far as $10 \mathrm{~mm}$. from the sclera. Foci of lymphocytes are not uncommonly seen scattered in the fat that fills out the muscle funnel.

C. Pathway of the virus into the optic nerve. The infiltration in the choroid presses through the emissaria that surround the scleral canal into the sulcus of the intervaginal space of the optic nerve where a large number of cells may accumulate. On the way through the sclera the circle of Zinn may be enmeshed. Lymphocytic foci develop particularly along the pial sheath (Fig. 4). There is thus set up a sympathetic leptomeningitis of the intervaginal space. The infection is transmitted into the stem of the nerve by the pial sheath and the septal system derived from it; very rarely a typical nodule may be found some $12 \mathrm{~mm}$. back of the lamina cribrosa. It is important to state here that the sheaths of the optic nerve are involved only in far advanced cases. The choroidal infiltration may make its way forward around the 


\section{Participation óf the Ocular Appendages in Sympathetic}

OPHTHALMIA AND ITS BEARING ON ENUCLEATION

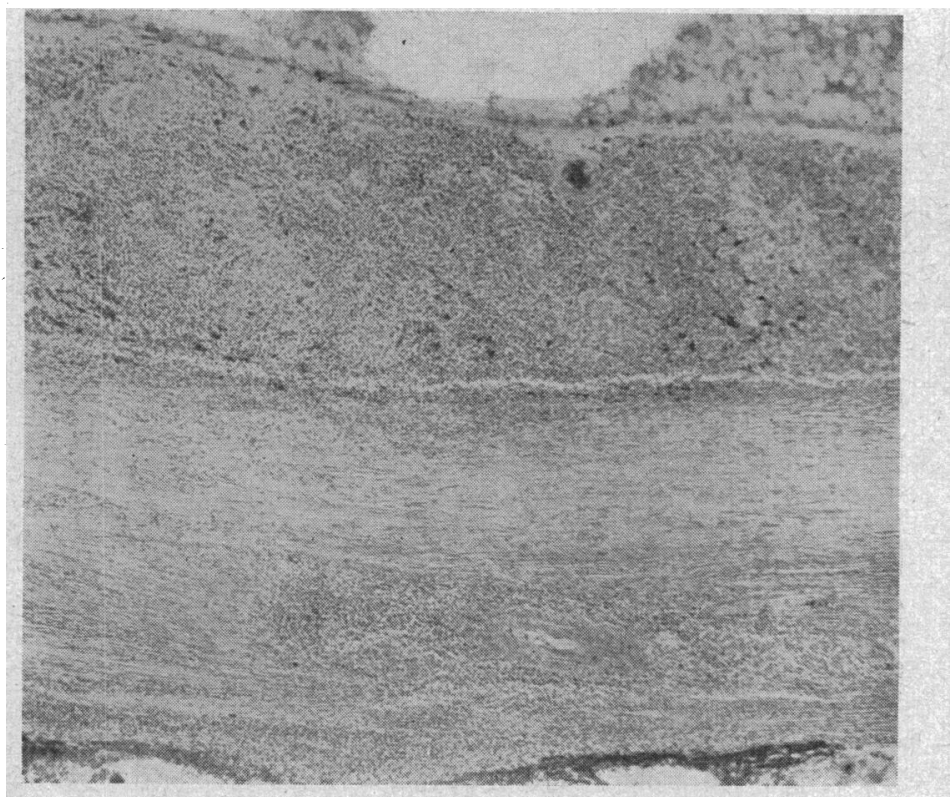

Fig. 3.

The outer and inner layers of the sclera in the posterior quadrant are undergoing destruction. Lymphocytic foci are scattered in the middlelayers. The overlying choroid shows an infiltration of lymphocytes, epithelioid cells and giant cells in its purest form. Similar elements. have replaced the external layers of the sclera.

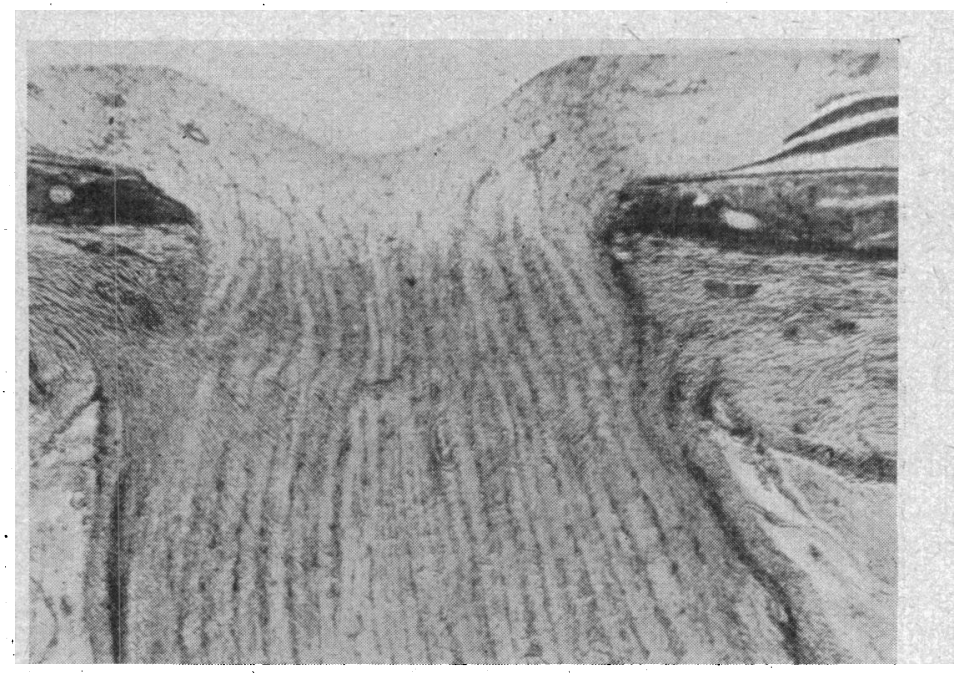

FIG. 4.

Files of lymphocytes infiltrate and separate the layers of the pial sheath. Note that infiltration extended beyond the point of excision. 


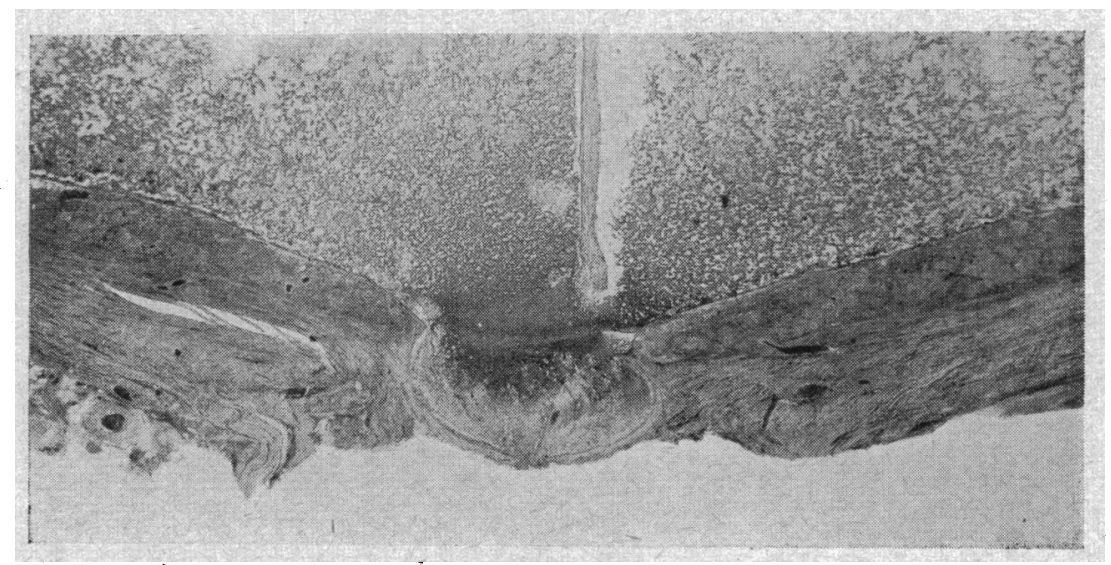

Fig. 5.

The optic nerve was excised within the scleral canal no doubt leaving much infected material behind. Small lymphocytic foci can be made out in the fat to the left.

opening in the lamina vitrea and appear as a collar surrounding the papilla. It is certain that the infection is not transferred to the - other eye through the optic nerve and chiasm because the opposite nerve never shows signs of ascending inflammation.

\section{Enucleation of the Exciting Eye}

McKenzie, who in 1835 wrote the first scientific description of sympathetic ophthalmia, seems to have made no suggestion as to its prevention, although he prescribed a number of palliative remedies. It remained for Prichard, in 1851, to advise the excision of the injured eye, but only after the fellow eye began to show signs of inflammation. In a few cases, probably those in the prodromal stage, the removal of the offending eye did arrest the process in the uninjured eye, thus adding further proof to the sympathetic nature of this disease. In most cases the condition continued to grow worse and in a few it seemed to be actually aggravated by the excision of the injured eye so that there grew to be considerable opposition to the operation.

Later, the crowning surgical step was made by Critchett, who advised the removal of the injured eye before there are any signs whatsoever of iridocyclitis in the other. In the active stage of any form of iritis Critchett took a strong stand against any attempt to perform an iridectomy, an operation which had been greatly overestimated as a cure for all kinds of iritis. It is the universal practice to-day to excise at once every globe which after a perforation shows 
retraction of the wound, hypotony, sensitiveness either spon-taneously or to light touch, and failing vision.

The object now is to apply with discretion the histological facts to the procedures for the removal of the exciting eye. 'Whenever enucleation is performed as a preventive measure the ordinary method of cutting the nerve on a level with the outer surface of the sclera may be employed with safety. Once signs of sympathetic ophthalmia appear the only hope of saving the uninjured eye lies in the immediate removal of the source from whence came the invasion and from which fresh virus would constantly be sent forth. Before operating it is possible to gain valuable information from examination of the sympathising eye as to the state of the infiltration in the injured eye and its appendages. If central synechia of the iris can be partially broken up and kept under control it is likely that the infiltration is in the first stage in the injured eye or at least is still intra-ocular. Should the iris be swollen and discoloured or, most important of all, should the pupillary zone be hopelessly bound down, these are signs that the inflammation has reached its acme in the exciting eye and that the extra-ocular structures are infected.- The difficulty of removing an acutely irritated and painful globe surrounded by orbital cellulitis seems to account for the many instances in sympathetic ophthalmia in which the optic nerve is cut within the scleral canal. A long strip of the inferior oblique muscle should be excised and the optic nerve and the retrobulbar tissues around it should be removed almost to the apex of the muscle funnel. The wound should be left open to drain. If there remain in the exciting eye some degree of vision it is axiomatic to postpone enucleation as the benefit of the operation is always problematicaland there is no justification for sacrificing even the faintest vision.

\title{
LINDAU'S DISEASE-PROGRESSION IN AFFECTED FAMILY
}

\author{
BY \\ Alexander E. MacDonald \\ TORONTO, CANADA
}

IT is unfortunate that Lindau's disease has been inextricably associated with allied conditions in so many published reports of the clinical findings and pathological records. It is a rare condition, and to substantiate the diagnosis it seems reasonable to require that the presence of multiple haemangioendothelioma be verified, for at 